\section{IJ§ER}

ISSN: 2149-5939
International Journal of Social Sciences and Education Research

Online, http://dergipark.gov.tr/ijsser

Volume: 3(5), 2017

\title{
Evaluation of the desserts; which are hosmerim, cheese halva, kunafah produced in Turkish cuisine -in aspect of tourism
}

\author{
Yılmaz Seçim ${ }^{1} \quad$ Gürkan Uçar ${ }^{2}$
}

Received Date: 10 / 02 / 2017

Accepted Date: 11 / 07 / 2017

\begin{abstract}
Turkish Cuisine is shown among the top three cuisines in the world by many sources. It is a fact that he deserves more than this title. From the beginning of 1990's Turkish cuisine has been presented to the tourists who coming to the country with the development of tourism. But some meals such as kebab, döner are on the foreground, while höşmerim (a sweet made of unsalted cheese), cheese halva, kunafah did not find the place that they deserved. On the other hand, tiramisu with cheese and cheesecake consumed by many people, in the world. In order to bring the desserts produced by the cheese into the forefront, tourists should be included from the beginning of this making process. With this method, new destination areas will be formed and at the same time the recognition of Anatolian culinary cultures will be increased.
\end{abstract}

Keywords: Cuisine, kunafah, cheese halva, hosmerim

\section{Introduction}

People's expectations and requests in tourism are changing rapidly therefore there is also an increasing need for more types of touristic products. The main purpose of the diversification of the touristic products is to preserve and add to all the cultural, economic and ecological values. Apart from that, the objective is to jump out of the sea-beach-sun framework, and to spread the touristic activities throughout Turkey's all regions within all four seasons. Since the beginning of $90 \mathrm{~s}$, with the increasing emphasis on the sustainable tourism the rural tourism all around the world and especially in Turkey gain huge importance. Nowadays, people started to increasingly pay more attention to what they eat and what they drink. One of the soundest proofs for this is that almost every single newspaper has sections or news that is related to food and drinks. In addition to that, In the United States of America the number of the bazaars and outdoor markets increased from 1775 to 6132 from year 1994 to 2010, which is an increase of 245,5\% and which is a testimony to the fact that organic local food had gained lot of importance. As the all tourism figures, our culture of food and drinks can be associated with rural tourism, and it can also be described as the cultural representation tool enhancing attraction of destination. Turkey is a country with splendid foods and beverages culture and this advantage is to be evaluated in many fields (Kesici, 2012). In terms of requests that tourists make, along with the changes that occur, it can be seen that consumers became more experienced, more selective and more inclined to enjoyment. This new type of tourists chooses more active, authentic values oriented, nature balance sensitive and ethically proper sort of trips (Demir and Çevirmen, 2006). The number of this group of tourists is increasing and they are becoming standard phenomenon. In

\footnotetext{
${ }^{1}$ Research Asst., Necmettin Erbakan University, Tourism Faculty, Gastronomy and cuisine Art Department KonyaTURKEY, ysecim@,konya.edu.tr

${ }^{2}$ Prof. Dr.,Selçuk University, Veterinary Faculty Food Hygiene and Technology Department, Konya-TURKEY, gucar@selcuk.edu.tr
} 
Seçim, Y., Uçar, G. (2017). Evaluation of the desserts; which are hosmerim, cheese halva, kunafah produced in Turkish cuisine -in aspect of tourism. International Journal of Social Sciences and Education Research, $3(5), 1478-1484$.

this sense, rural tourism following the understanding of Eco tourism has an utmost importance with the nature friendly development strategy. It is quite clear that in order to reach a certain necessary level of attractiveness, rural tourism needs auxiliary touristic products that must be well prepared and administered. It is beyond dispute that among these products premiere place is reserved for great variety of local foods and drinks that have both historical background and are very diverse. Gastronomy tourism has already been included in the catalogs of many countries, yet it is still far away from the place it deserves in Turkey's tourism.

\section{Gastronomy and the role of foods-drinks in the tourism}

The word gastronomy can be defined as "shaping the culture of food and drink into science and art" (Doğdubay, Sarığlan, Saatçi and Eroz, 2011). Beside of enjoying the good foods and beverages, the science of gastronomy is reinforced with the relationship between gastronomy and perfection. The gastronomy and culinary tourism can be defined as a tourism type which highly contributes the behaviors and journey motivation to experience unique foods and beverages (Wolf, 2006). Gastronomy plays important role in advertising some touristic destinations (Kivela and Crotts, 2005). For instance, Toscana in Italy built its image based on its foods and drinks. The rich people of Western Europe go on tours to eat goat cheese and drink wine (Denizer, 2008). Some of the travel agencies have regular trip offers for gastronomy tours in Asia and Europe (Kivela and Crotts, 2005). Gastronomy products had become integral part of touristic destinations and became touristic product on their own, having great importance in shaping the image of the touristic destination. If we were to mention several examples:

In Italy and France, there are gastronomy and taster tours, whereas in Toscana and its surrounding cooking classes are available (Kivela and Crotts, 2005). In Spain on the other hand, tours offer a lot of appealing different alternatives such as going around rural areas in quest for mushrooms, visiting local markets, visiting local cheese manufacturers, tasting locally produced olive oil, visiting wine producers and tasting wine and lastly upper level cooking classes all along with possibility of staying in local or luxury places.

In Europe, coutries such as Spain, Italy, Portugal, France and Ireland directed their attention to gastronomy excursions. Activities that take place in these excursions usually are:

- Visit to the local cheese manufacturers

- Workshop cheese studies

- Looking for mushrooms in rural areas

- Tour the local markets

- Visit olive oil manufacturers and taste the olive oil

- Upper level food classes

- Smokehouse tours (structure to dry meat and fish with wood incense and store them)

- Vineyard visits and vine-harvest activities

- Tours whose objective is to receive education on Wine production, visiting Wine manufacturers and tasting Wine

- Tours that include local food or drinks festivals

- Home cooking classes 
Seçim, Y., Uçar, G. (2017). Evaluation of the desserts; which are hosmerim, cheese halva, kunafah produced in Turkish cuisine -in aspect of tourism. International Journal of Social Sciences and Education Research, 3(5), 1478-1484.

Food was associated with travel since the prehistory times. The relationship between gastronomy and tourism advanced till the development of the terms of hospitality, kitchen and taste-innovative gastronomy tourism (Amira, 2009). If we think about the social functions of the food, and the symbolic meaning it has while putting these functions into practice, it is visible that food is a clear indication of the strength of society. Aforementioned strength can be easily seen in the strength relationships in the most basic division of food distribution and food consumption (Beşirli, 2010). Participation into tourism phenomenon and the utilization way from the activities in that phenomenon exhibit similarities with the differences that foods form in the society. On the other hand, there is a conclusion that activities related to foods and drinks are the primary unifying elements of the tourism sector (Doğdubay et al., 2011). Tourism phenomena is something that makes countries familiar with each other and it is beyond any discussion about the role that food plays in this process. A tourist goes to another country or region, eats their food, tries out new tastes and enjoys them (Gökdemir, 2005). Today, gastronomy has become one of the most important factors that determine the selection of the holiday resort. Among the expectations that the tourists have from another country, besides sightseeing and meeting new cultures, there is also tasting new foods and gain new experiences (Doğdubay et al., 2011).

\section{Cheese}

It is know that the first cheese was produced by Sumerians, the people who lived in the south Mesopotamia between 2000 and 4000 years BC. People who were living nomadic type of life, after they learned that they can obtain milk from cows, sheep and goats, had decided to carry the milk to places they would move to. In order to carry the milk, they would use the material that they obtained from the stomach of animals such as sheep or cow. Nomadic people discovered that they can eat the cut pieces of the cheese which is obtained from curdling in the stomach due to enzymes and drink its liquid parts. (Scott, 1981; Swan, 2009). The first technology of producing the cheese was developed during the Roman times and that knowledge was furthermore carries into Europe. The main cause for cheese production in Roman times was protracting the retention period of the milk, which can be gotten sour easily due to bacteria in it, by making it more durable (Walter, Alexandra, Sieber and Wethmüller, 2008).

The factors that make the cheese consumption on a daily basis so important include its easy digestion, and salts, vitamins, serum proteins and many other nutrition elements that can be found in certain amounts in the cheese. Cheese is especially rich with high-quality proteins, fats, calcium, A vitamin and B12 vitamin (Akın, 2006). Besides the need to satisfy our physiological hunger, the daily consumption of cheese also meets the needs of our body for some crucial nutrition elements. Hand in hand with the improvement in technological processes, variety of cheese with specific textures and flavors that are being produced also improved. The cheese contains high biological value of proteins. In accordance with the brand of cheese, protein values vary from $4 \%$ to $40 \%$ (Brine and O'Connor 2000).

\section{The place of cheese in Turkish cuisine}

The food that people use in their nourishment may change according to several factors among which are the natural conditions, economic conditions, tradition of the society or customs. Due to high variation of types of cheeses, some cheeses are produced in certain localities 
Seçim, Y., Uçar, G. (2017). Evaluation of the desserts; which are hosmerim, cheese halva, kunafah produced in Turkish cuisine -in aspect of tourism. International Journal of Social Sciences and Education Research, 3(5), 1478-1484.

traditionally. The variety of cheese in Turkey is very high, and there are approximately 200 different types of cheese present. With the fact that these 200 cheese types have some differences, there are 12 main types of cheese. In our country, apart from breakfast, the cheese is being used in main meals, cakes and desserts. The reason behind the great variety and progress in terms of cuisine in the Turkish society is the connection that exists between the social customs and the food. In order to mark a certain product as traditional, the product has to be related to a certain area and the process of production has to follow certain traditional procedure. Specific climate conditions and wide range of specific factors in production allow the traditional products to earn huge importance and value in the trade market (Jordana, 2000). Traditional foods comprise products that are produced by using specific traditional methods and traditional raw materials that are unique only to a particular area such as siyabo plant which is used in Van herby cheese (Demirbaş, Oktay and Tosun, 2006). Along with the diversification of types of cheese, apart from cheese produced for the commercial purposes there are also many different types of local cheese that can be found everywhere in Turkey. Besides being produced by using various different techniques, local types of cheese also reflect the culture of the area they belong to (Tan, 2004). Some of cheeses produced traditionally are produced in modern commercialscaled milk operations and most of them are produced in the sector of home economics; and therefore quality and standards requested cannot be obtained (Tan and Ertürk, 2002).

\section{The desserts made by using cheese in Turkey}

Turkish cuisine is known as one of the oldest and richest cuisines. Diverse and rich as it is, it contains different types of broths, olive oil meals, kebab, different types of rice, stuffed vegetables, syrups, sherbet desserts and cheese and milk desserts. Vast variety in geography and the climate conditions have important impact on the enrichment of the Turkish cuisine. Due to this variety, on local levels many different types of food cultures take place. For instance, in the Mediterranean Sea region people put emphasis on vegetables consumption, whereas in the East and in the South East meat and meat products are being consumed at a large scale (Birer, 1991; Baysal, 1993; Sürücüoğlu and Akman, 1998). In the Turkish cuisine, desserts have special place. A quote which says "Let's east sweet and talk sweet" is among the quotes that reflects the impact of sweets on the daily life of people. The crucial characteristics of Turkish delights are that they contain high energy and bring lot of joy and satisfaction to the consumer. These characteristics are related to the ingredients used in delights. In the same manner as they are consumed on everyday basis in specific hours, desserts are also frequently served on special occasions such as birth, demise, military service, engagement and graduation (Tezcan 2000). Foods which contribute to the traditional, historical and cultural heritage that may appear to be similar, are being divided by following criteria; they have specific characteristics, they are produced by using traditional materials and components or prosses original composition and are produced by using original traditional methods (Gürsoy, Kesenkaş and Kınık, 2008).

\subsection{Hosmerim}

Hosmerm, is known as a yellow homemade dessert that has been prepared with a unique method for more than 500 years in Balıkesir's Havran district. In the travel book written by Evliya Çelebi, it is explained that this delight had been seen in the first Turkish settlers in Trabzon, and that it was then passed to Havran from there (Dağl1, Kahraman and Kurşun, 2006). It is 
Seçim, Y., Uçar, G. (2017). Evaluation of the desserts; which are hosmerim, cheese halva, kunafah produced in Turkish cuisine -in aspect of tourism. International Journal of Social Sciences and Education Research, 3(5), 1478-1484.

assumed that the first Höşmerim was produced by the nomads who moved from Middle Asia to Anatolia (Ünsal, 2003).

Hosmerim, which used to decorate Ottoman cuisine as well, has a prominent place among the Turkish delights as well. It was produced especially in the Aegean, Black Sea and Middle Anatolian area. Today on the other hand, it is mainly produced in Balıkesir, Bursa, Çanakkale, Tekirdağ, Kırklareli and İzmit provinces (Ünsal, 2003). Hosmerim is being produced in many different provinces, hence the methods of its production appear to be very different (Şahan, Yiğit, İrkin and Korukoğlu, 2006). Hosmerim is being produced by salt-free fresh cheese, sugar, flour or sometimes even semolina. In addition, hosmerim in Konya is being produced by adding Turkish cream instead of milk (Taş, 2004; Halıc1, 2014). Previously hosmerim was produced only made in the homes, and the first know industrial hoşmerim was made between 1985 and 1990 in Balıkesir province.

\subsection{Cheese halva}

Beloved cheese halva delight is being produced in different areas and it is known by different names. It is among the most consumed traditional sweets in Tekirdağ. Tekirdağ people especially love to consume this sweet during the summer. In time, the production of cheese halva became widespread and the product is now easy to find on the market due to the fact that it is being produced in cake and special cheese halva factories, and due to the fact that the distribution takes place in grocery stores, shops or supermarkets (Şener, Kolukırık and Eti, 2010).

The most important stage in the manufacturing of the cheese halva is to melt the salt-free fresh cheese on the fire until it becomes homogeneous mixture. Mistakes that are made in this phase influence the final product's characteristics so that it may become too stiff or nonhomogenous. It is vital to control the melting process closely and to develop new techniques that may affect the position of this delight in the future (Evyapan, 1995).

\subsection{Kunafah}

Known widely as a delight from Mediterranean region, kunafah is a dessert that is made from cheese and kadayıf and it is served while hot. In old Arabian cook books word the word kinafa exists, however the meaning of the word does not refer to shredded wheat in syrup but it refers to the thin spread dough. In the $13^{\text {th }}$ century cook book called Kitabü'l-vusla, there is a recipe of kinafa which can be done by cutting the thin paste as lanes. Previous to this, in the $11^{\text {th }}$ century Divanü Lügati'ü Türk (Compendium of the Turkish Languages) a similar delight to künefe was mentioned.

In Turkey, starting with Hatay, kunafah is being produced in variety of ways in Mersin, Adana, Gaziantep, Kilis, Şanlıurfa, Diyarbakır and Mardin. For kunafah cheese production cow milk is preferable. Although there are many different types of kunafah, generally the manufacturing process is always the same. Salt-free fresh cheese is being put between two layers of kadayif and it is then cooked while at the same time, non-stiffen sugar syrup is being poured upon. The differences in the final product are result of different types of cheese and kadaylf used in the process. As far as the cheese is concerned fresh cheese types that are closer to raw milk such as Hatay cheese, Lor cheese, Antep and Urfa cheese are being predominantly used. Since these 
Seçim, Y., Uçar, G. (2017). Evaluation of the desserts; which are hosmerim, cheese halva, kunafah produced in Turkish cuisine -in aspect of tourism. International Journal of Social Sciences and Education Research, $3(5), 1478-1484$.

types of cheese are both difficult to produce and to keep fresh, in the home recipes string cheese can also be encountered

\section{Conclusion and suggestions}

Nowadays, since gastronomy tourism is gaining more value, a need for new destinations is eminent. Turkey is just like a mosaic because throughout the country there are many different cultures therefore the consumption habits show great variations. Especially in areas that suffer from difficult economic conditions, where most of the necessary food cannot be founded, milk has become the most important part of nutrition. However, as milk is not very endurable on its own, in time cheese obtained from milk was largely put in use. In Turkish society, cheese is used in breakfast, pastry, in meals and in desserts. In this research the cheese desserts had been discussed, which represents only a tiny area of cheese usage. Since tourism has inclination towards food and beverages, this is an area that has to be improved. One of the biggest problems related to cheese is that is it being produced differently in different areas which means there is no single unique recipe for it. Since there is no recipe, in time there is a danger that the cheese produced can lose some of its characteristics or that the recipe can be completely forgotten. In addition to that, not having a recipe can lead to huge variations in terms of taste can occur. Another issue is that cheese desserts are not being produced industrially. Generally, the product is both produced and consumed by the people themselves therefore there is an obvious problem of advertising the product. Industrially produced desserts can be spread to more people and areas, therefore making the product more recognizable. One of the main reason of that cheese types are well-known in the world is the active participation of tourists who by their participation contribute to the formation of destination areas. For example, the herbs used in herby cheese produced in Van province can be efficiently advertised in a manner that the tourists would collect the herbs from the mountains and then produce the cheese on their own. To ensure that tourists participate and learn about the production would invigorate the tourism overall.

\section{References}

Akın, N., Ayar, A., Sert, D. (2006). Bazı peynir çeşitlerinin mineral kompozisyonu ve beslenme yönünden önemi. Türkiye 9. Gida Kongresi.

Amira, F. (2009). The Role of Local Food in Maldives Tourism A Focus on Promotion and Economic Development. Tourism Research Institute, New Zealand.

Baysal, A. (1993). Changes in Turkish culture of cuisine, evaluation in sight of health and nutrition. In: Researches in Turkish Culture of Cuisine. Türk Halk Kültürünü Araştırma ve Tanıtma Vakfı, Yayın No: 3, Ankara.

Beşirli, H. (2010). Yemek, Kültür Ve Kimlik, Millî Folklor, Yı1 22, Say1 87.

Birer, S. (1991). The dia chronic change of Turkish cuisine and its current aspect. Milli Kültür 87, 47-50.

Brien, M.O., O'Connor, T.P. (2000). Nutritional Aspects of Cheese, In: Patrick, F.F. et al. (Eds), Cheese, Chemistry, Physics and Microbiology, Volume 1, General Aspects, Third Edition, Elsevier, Inc, USA, 572-579.

Dağl1, Y., Kahraman, S.Y., Kurşun, Z. (2006). Evliya Çelebi Seyahatnamesi. 9. Kitap. Yapı kredi yayınları, İstanbul.

Demir, C., Çevirmen, A. (2006). Turizm ve Çevre Yönetimi, Nobel Yayın Dağıtım, Ankara s. 56.

Demirbaş, N., Oktay, D., Tosun, D. (2006). AB sürecindeki Türkiye'de Gıda güvenliği açısından geleneksel gıdaların üretim ve pazarlanması, HR.Ü.Z.F. dergisi , 10 (3/4):47-55. 
Seçim, Y., Uçar, G. (2017). Evaluation of the desserts; which are hosmerim, cheese halva, kunafah produced in Turkish cuisine -in aspect of tourism. International Journal of Social Sciences and Education Research, 3(5), 1478-1484.

Denizer, D. (2008). Türk Turizminin Gelişmesinde Türk Mutfağının Önemi ve Bugün İçin Yapılması Gerekenler. III. Balıkesir Ulusal Turizm Kongresi, Balıkesir.

Doğdubay, M., Sarığlan, M., Saatçi, G., Eroz, S. (2011). Destinasyon Pazarlamasında Yerel Yönetimlerin Gastronomik Öğeleri Kullanma Ĕgilimlerinin Ölçülmesine Yönelik Bir Araştırma. V. Ulusal Gastronomi Sempozyumu, Antalya.

Evyapan, Ö. (1995). Balıkesir yöresi Hösmerimleri ile Tekirdağ yöresi peynir Helvalarının Fiziksel Kimyasal ve Mikrobiyolojik Özellikleri Üzerine Bir Arastırma. Yüksek Lisans Tezi T.Ü. Gıda Müh. Böl. Tekirdağ.

Gökdemir, A. (2005). Mutfak hizmetleri yönetimi Detay yayıncıl1k Ankara (8-9).

Gürsoy, O., Kesenkaş, H., Kınık, Ö. (2008). Avrupa birliğine girişs sürecince geleneksel gıdalarımızın bilimsel, sosyolojik ve ekonomik açıdan değerlendirilmesi, Türkiye 10. G1da Kongresi, S:145-149, Erzurum.

Güvenç, B. (1996). Food, culture and food culture. In: Eskimeyen Tatlar, Türk Mutfak Kültürü. Vehbi Koç Vakfı Yayın No: 7, İstanbul, p. 13-17.

Halıc1, N. (2014). Mevlevi Mutfă̆ı, 1. Bask1, Metro Kültür Yayınları-1. İstanbul.

Kerstin, U., Blom, N., Weren, O. (2009). Cheese and Cheese Making, Bioscience Explaned, 1, (2): Sweeden.

Jordana, J. (2000). Traditional foods. Challenges facing the European food industry, Food Research International 33, p.147-152.

Kesici, M. (2012). Kırsal Turizme Olan Talepte Yöresel Yiyecek ve İçecek Kültürünün Rolü. KMÜ Sosyal ve Ekonomik Araştırmalar Dergisi, 14 (23): 33-37.

Kivela, J., Crotts, J. C. (2005). Gastronomy Tourism: A Meaningful Travel Market Segment, Journal of Culinary Science \& Technology, Vol. 4(2/3).

Scott, R. (1981). Cheese Making Practise, Applied Science Publishers Ltd, London, UK.

Sürücüoğlu, M.S., Akman, M. (1998). The dia chronic change of Turkish cuisine and the current reasons for this change. Standart 37 (439), 42-45.

Swan, S. (2009). Türkiye'nin Peynir Hazineleri, boyut yayın grubu. İstanbul, ISBN: 978-975-23-0067-5.

Şahan, Y., Yiğit, A., İrkin, R., Korukoğlu, M. (2006). Höşmerim tatlısının kimyasal ve mikrobiyolojik özelliklerinin belirlenmesi. Türkiye 9. Gida Kongresi, 24-25 Mayıs, Bolu.

Şener, T., Kolukırık, C., Eti, S. (2010). Geleneksel Gldalarda Pazarlama Ve Girişimcilik: Tekirdă̆ peynir helvası örneği. Uluslar arası 2. Trakya bölgesi Kalkınma-Girişimcilik Sempozyumu, 1-2 Ekim, İğneada-Kırklareli.

Tan, E. (2004). Türkiye Geleneksel Gıda Ürünleri Projesi, Tarım ve Köyişleri Bakanlığı Tarımsal Araştırmalar Genel Müdürlüğü Gıda Kontrol ve Merkez Araştırma Enstitüsü, Bursa.

Tan, S., Ertürk, E.Y. (2002). Peynir, tarımsal ekonomi araştırma enstitüsü. bakış dergisi, sayı:1 nüsha:11.

Tezcan, M. (2000). Anthropology of Turkish food. Genç Ofset, Ankara, p.148.

Ünsal, A. (2003). Süt uyuyunca, Türkiye peynirleri. YKY Yayınları, İstanbul s. 221.

Walter, B., Alexandra, S., Sieber, R., Wehtmüller, K. (2008). Cheese in Nutrition and Health, Dairy Science and Technology. 88. (4-5) : $389-405$.

Wolf, E. (2006). Culinary tourism: The hidden harvest. Dubuque, IA: Kendall/Hunt Publishing Company. 